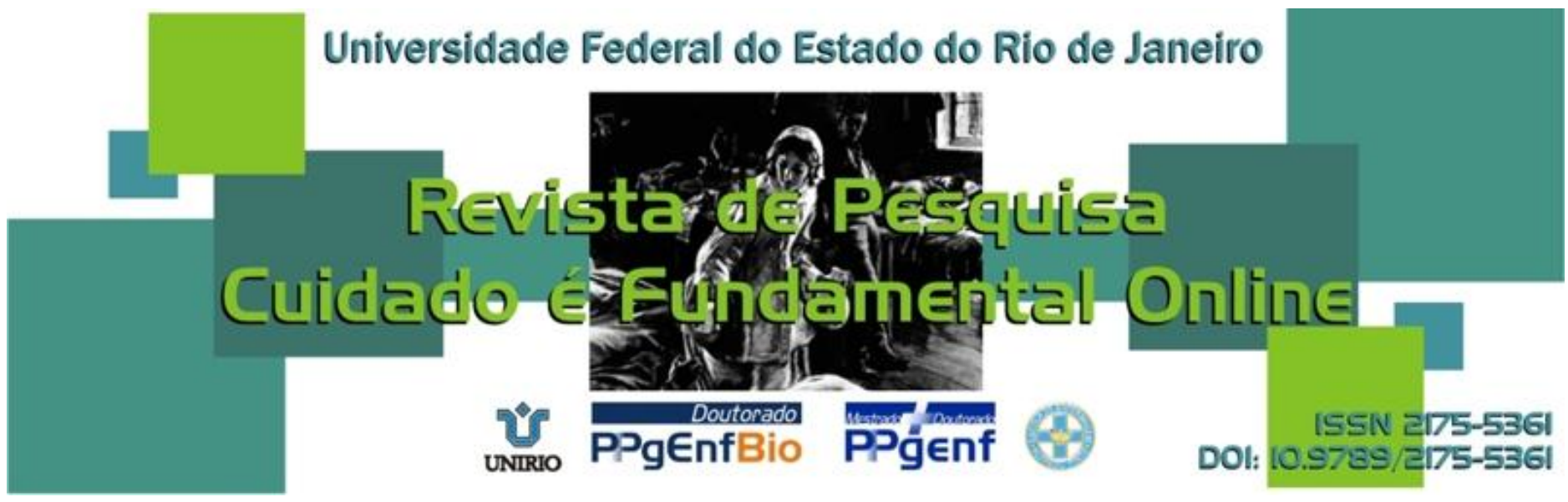

\title{
RESEARCH
}

\section{SEMIOLOGY OF MEETING: IMAGES OF PRACTICES AMONG TEACHERS AND HIGH SCHOOL AND ACADEMIC} STUDENTS

SEMIOLOGIA DO ENCONTRO: IMAGENS DAS PRÁTICAS ENTRE DOCENTES E ALUNOS DO ENSINO MÉDIO E UNIVERSITÁRIO

SEMIOLOGÍA DE LA REUNIÓN: IMÁGENES DE LAS PRÁCTICAS ENTRE PROFESORES Y ALUMNOS DE LA ESCUELA SECUNDARIA Y DE LA UNIVERSIDAD

Eva Maria Costa ${ }^{1}$, Monica de Almeida Carrreiro ${ }^{2}$, Nébia Maria Almeida de Figueiredo ${ }^{3}$,

Carlos Roberto Lyra da Silva ${ }^{4}$, Priscila de Castro Handem ${ }^{5}$, Teresa Tonini ${ }^{6}$

\begin{abstract}
Objectives: To show pictures of the meetings with teachers and High School and academic students as an inductor of a Semiology of Meeting, as well as to analyze by inferentially discussing on the produced images as an inductor of a Semiology of Meeting. Method: Qualitative, by making use of the cartographic method of KASTRUP and ESCOSSIA ${ }^{1}$. Results: 74 images containing 135 students of two different degrees and 06 teachers, besides 35 images (pictures) of 90 students who, depending on situation and who spoke at the meetings, presented their bodies aware or contained in itself (17), relaxed and cheerful(28) and mindful and expectant (45). Conclusion: This study is the first step towards the Semiology of Meeting, which makes sense as a technical procedure of welcoming. This conception might indicate us the creation of further nursing domains, in increasingly differentiated ambits of the social life, by bringing us new vectors and expectations arising from a diverse nature in the current context. Descriptors: Extension, Teenage Health, Nursing Care.

RESUMO

Objetivos: Mostrar imagens das reuniões com docentes e discentes do $3^{\circ}$ e $2^{\circ}$ graus como indutores de uma Semiologia do Encontro e analisar discutindo inferencialmente as imagens produzidas como indutoras de uma Semiologia do Encontro. Método: Qualitativo, com a utilização do método cartográfico de KASTRUP e ESCOSSIA ${ }^{1}$. Resultados: 74 imagens contendo 135 estudantes dos dois graus e 06 docentes, além de 35 imagens (fotos) de 90 estudantes que dependendo do espaço e de quem falava nas reuniões, apresentam-se com os corpos ouvintes ou contidos em si mesmos (17), relaxados e alegres (28) e atenciosos e expectantes (45). Conclusão: Este estudo é o primeiro passo para uma Semiologia do Encontro, a qual tem sentido como um procedimento técnico do acolher. Essa concepção pode nos indicar a criação de novos domínios para a enfermagem, em instâncias cada vez mais diferenciadas da vida social, incorporando em nós novos vetores e expectativas de natureza diversa no contexto atual. Descritores: Extensão, Saúde do adolescente, Cuidado de Enfermagem.
\end{abstract}

\section{RESUMEN}

Objetivos: Mostrar imágenes de los encuentros con profesores y estudiantes de los grados $3^{\circ}$ y $2^{\circ}$ como un inductor de una semiología del encuentro e analizar debatiendo de modo inferencial las imágenes producidas en la inducción de una semiología del encuentro. Método: Estudio cualitativo, mediante la utilización el método cartográfico de ESCOSSIA1 y KASTRUP. Resultados: 74 imágenes conteniendo 135 estudiantes de diferentes grados y 06 profesores, que muestran 35 imágenes (fotos) de 90 estudiantes que, dependiendo del espacio y del orador de las reuniones, se quedan oyentes y tienen los cuerpos contenido en su mismo (17), relajado y feliz (28) y atento y expectante (45). Conclusión: Este estudio es el primer paso a una semiología del encuentro que tiene sentido como un procedimiento técnico de abrigar. Este diseño puede revelar la expansión de nuevas áreas de la enfermería en casos cada vez más diferenciados de la vida social, incorporando en nosotros los nuevos vectores de expectativas de índole diversa en el contexto actual. Descriptores: Extensión, La salud del adolescente, La atención de enfermería.

${ }^{1}$ Adjunct Professor from the DEF/EEAP/UNIRIO. Doctorate's Student from the Nursing and Biosciences Doctorate Programme /UNIRIO. E-mail: evamariacosta@ig.com.br. ${ }^{2}$ Nurse. PHD in Nursing/UFRJ. E-mail: carreiroma59@gmail.com Nursing. ${ }^{3}$ Nurse. PHD in Nursing/UFRJ. Titular Professor from the DEF/EEAP/UNIRIO. E-mail: nebia@unirio.br. ${ }^{4}$ Nurse. PHD in Nursing/UFRJ. Adjunct Professor from the DEF/EEAP/UNIRIO. E-mail: profunirio@gmail.com. ${ }^{5}$ Nurse. Doctorate's Student from the Nursing and Biosciences Doctorate Programme/UNIRIO. E-mail: priscilahandem@yahoo.com.br. ${ }^{6}$ Nurse. PHD in Collective Health/IMS/UERJ. Adjunct Professor from the DEF/EEAP/UNIRIO. E-mail: ttonini@terra.com.br.

R. pesq.: cuid. fundam. online 2013. abr./jun. 5(2):3684-91 


\section{INTRODUCTION}

This study is part of a Doctoral Thesis of the Nursing and Biosciences Program from the Alfredo Pinto Nursing School, Federal University of the Rio de Janeiro State (EEAP/UNIRIO), in liaison with the ExLIS Project - Extension in Image and Sound Laboratory (funded with support from the FAPERJ), which intends to investigate the health and environment of the High School young students.

Our lived experiences are resulting from the practice of teaching to take care, but not only in enclosed spaces of health institutions such as hospitals, clinics, health stations. We always hold a care practice or teach to take care, by adopting a gaze aimed at identifying disease, where knowing to identify or control the signs and symptoms has become our greatest skill in the medical knowledge field, since semiology is a knowledge established in this scope.

By leaving these spaces to invest in the care at the Extension, where it is possible to create models and technologies to take care as it is said in the Care Factory Program - a space to create health care models and technologies -, we have made discoveries when walking into other spaces and when playing other games. The other ways are results of an experience without walls, in which we were exposed, why not tell: drifting away.

Among several institutions that are connected with us, we were asked to develop a paper on health in a High School Institution, and in this routine of MEETINGS with its leaders, in order to define what we would do, we were wondering what we would do, being that this study objective is to answer the following question: Could the images produced during gatherings indicate pathways for a Semiology of Meeting?
By thinking about the meeting, we are interested in giving new features to the term welcome* not only in the sense of "ARRIVING and PROPERLY SERVE", but how to build this meeting, what images are created on it and the involved people. It could be printed in a non-verbal image able to contribute to Nursing, by giving it a communication type. Thus, we have established the following objective: images of meetings with college and high school students as inducers of a Semiology of Meeting; and as objectives: to present pictures of meetings with teachers and students from academic and secondary degrees as inducers of a Semiology of Meeting and analyze when inferentially discussing the images produced as inducers a Semiology of Meeting.

This present study is justified from the following considerations: the first concerns our interaction to seek, in the produced images, stuff indicator of a Semiology of Meeting that is constructed in the scope of two experiences in development: one Doctoral Thesis and the ExLIS Project. With this study, we will start to publish the outcomes; the second is the search for phenomena within the image that point out signals and signs of the meeting expressed in the body language of those involved; and the third is the ability to build further communication elements in the practice to meet the other to take care at the Extension that covers not only collective or community issues, but a semiology for the care actions, where the Meeting is the starting point.

The fundamentals that underpin the studied object concern the BODY as an expression of communication; the CARE as a central element of the Meeting; and the ENVIRONMENT where subject and care freely work, by creating possible images of the construction of a semiology.

* The welcome as act or effect of welcoming expresses in its several definitions, an approaching action, a "being with" and "being around", i.e., an attitude of inclusion.

R. pesq.: cuid. fundam. online 2013. abr./jun. 5(2):3684-91 
Such categories - BODY, CARE and ENVIRONMENT are placed in the MEETING, they happen and deal with the construction of the semiology that we seek.

Thus, the concepts which we have used define: ${ }^{2}$

BODY - like mine and of the other understood as the science of care, stated as minimum space that is freehuman, active-human, master of its own ideas, opinions, values and world view. It is an indivisible, single, own, biological, emotional, psychological, cultural, political, linguistic and social body, in conclusion, historical. Source and mediation of knowledge and skills through the memories set out therein; body is a place of expression and creation; with meaning and representations; listening, cognition, production of images, power and subjectivity; instituted and instituting power, which creates political movements for change; actual-emotional body (subjective-objective) is what brings about remembrances, we are what we remember, body and memory.

NURSING CARE - it is the nursing expression applied and not restricted to any specialty and nor to the hospital nursing, means a set of actions and acts of care developed in care situations and addressed to the healthy or sick person, the other people connected to it, the communities and the population groups, with the goal of promoting and maintaining comfort, welfare, safety, as far as possible, within the limitations of professionals and institutional possibilities; it is an unconditional action of the body that cares moved by several objective and subjective impulses, as feelings, emotions, knowledge and experiences.

Environment - it is the context and the inner and outer space in which people and groups are born and live, coexist and live together. This is a political space, for action, practice and knowledge, where there are people who care and who are cared for; microenvironment (hospitals and health stations), macroenvironment (collective and community scopes); location for construction and use of techniques and technologies; care processes production; ecological space where there are risks or not in the environment, such as: light, air, water, noises, furniture and belongings of customers and professionals; hygiene as a care towards the biological, chemical and physical risks, as well as the human relationships - where there might be tension, hostility, joy, environmental pleasure in experiences and socio-political-economic transversalities; location for constructing and reconstructing work models and methods, to relate, in short, to care.

\section{METHODOLOGY}

The choice of qualitative method can perform production-interpretation and decoding of images, as we intend to seek meanings which lead us to interpret what they tell us about the MEETING. Communication not only associated with "the words expressed, through parlance considered effective, parlance appropriate to the context, clear and facilitator for the message", but also discover, in the meeting, "non-verbal signals that involve sounds, body language, its limbs and head movements; and how the space, relationships, body appearance and feelings are used". 3:49 Finally, to create images of the Meeting through filming was to objectify expressions and attach them to save them as documents, after reading and inferences about thereof, in search of clues of a Semiology of Meeting.

\section{The method and the methodological moments:}

Method: it is a qualitative study for the production of images and data arising from 03 Meetings to plan health activities by means of a process based on the Cartographic Method of Gilles Deleuze, adopted by Passos, Kastrup and Escossia ${ }^{2}$ with varieties used by the researcher and the cartographer, namely: SCREENING, TOUCH, LANDING and RECOGNITION, and they are translated as a monitoring process (meeting) and not as the representation of the object. Thus, we have investigated a production process and, in such a process, CLUES that guide us to discuss,

R. pesq.: cuid. fundam. online 2013. abr./jun. 5(2):3684-91 
Costa EV, Carreiro MA, Figueiredo NMA et al.

describe and collectivize the images produced were identified.

- Location: all activities were developed in the Olinto Botelho da Gama State School (CEOGB), located in Pillars, which is a neighborhood of the north zone from the city of Rio de Janeiro.

- Target audience: the universe of this project, composed of high school students, amounts approximately 900 (nine hundred) young. The eligible population was determined from the listing of young people regularly enrolled, provided by the School's Principal. We have proposed as inclusion criteria: students who make up the social body of the first, second and third year of the High School Degree; who are aged between 15-19 years and who voluntarily agreed to participate in the health activities, after the approval of their respective parents or legal guardians.

- Ethical aspects: by considering the articulation of this Extension Project to the research, the ethical precepts established in the Resolution 196/96 were met. Thus, parents or legal guardians gave consent for the conduction of the health assessment of their children with filming and recording of the activities in which they were present, when signing the Free and Informed Consent Form.

- First moment: we SCREENED and LANDED in the Meetings to produce IMAGES: The first and second were in our territory, Alfredo Pinto Nursing School, Federal University of the Rio de Janeiro State (EEAP / UNIRIO) and the third was built on the territory of the Olinto da Gama Botelho State School. When ending this moment of SCREENING and TOUCH people, in the spaces where the research took place, we conducted a careful fluctuating attention to the territory and people, whether they were stopped or in motion, including us, which was identified as INITIAL RESEARCH STAGE - we have produced data/images in these meetings. The signs and the forces that surround R. pesq.: cuid. fundam. online 2013. abr./jun. 5(2):3684-91

\section{Semiology of Meeting...}

the assembly of the work gave rise to this research process that involves quantity and quality.

- Second moment: we landed to identify signs (semiology) at the Meeting in the three photographic moments.

- Third moment: it was comprised of the results and the inferential analysis of produced images. 74 images were produced, as shown in Table 1.

\begin{tabular}{|c|c|c|c|}
\hline \multicolumn{2}{|c|}{ Total of pictures (images) } & \multicolumn{2}{c|}{ Total of students } \\
\hline $\begin{array}{c}\text { EEAP - } \\
\text { Academic } \\
\text { Degree }\end{array}$ & $\begin{array}{c}\text { CEOGB - } \\
\text { Secondary } \\
\text { Degree }\end{array}$ & $\begin{array}{c}\text { Academic } \\
\text { Degree }\end{array}$ & $\begin{array}{c}\text { Secondary } \\
\text { Degree }\end{array}$ \\
\hline 12 & 62 & 90 & 45 \\
\hline \multicolumn{2}{|c|}{74} & \multicolumn{2}{|c|}{135} \\
\hline
\end{tabular}

Table 1 - Concerning the images of the meeting of the territories

We have highlighted some images that represent the three meetings for having a general idea.

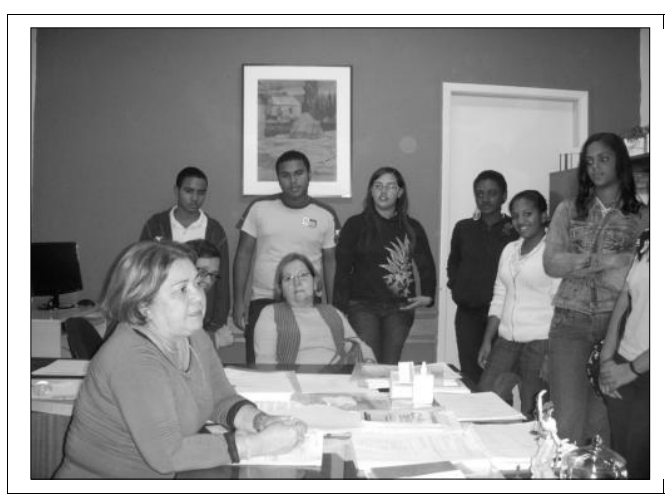

Image 1 - Presentation on the University and the EEAP, at the EEAP's Principal Room

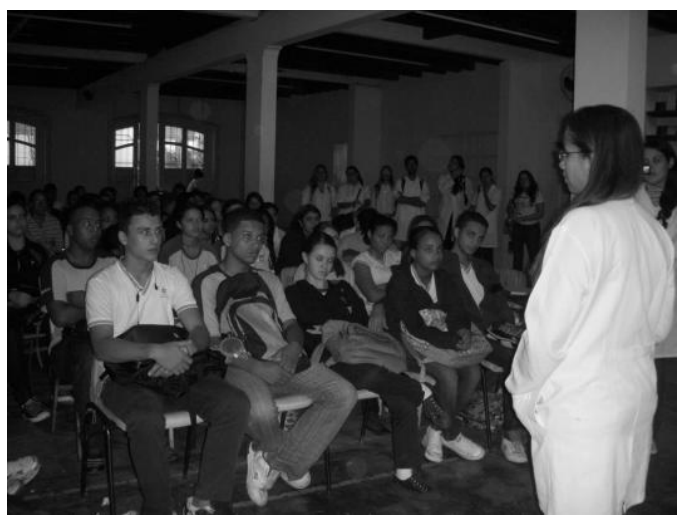

Image 2 - Academic of the $3^{\text {rd }}$ term of the Undergraduate Nursing Course aware of the asking that is being conducted by the student of the $3^{\text {rd }}$ High School grade. 


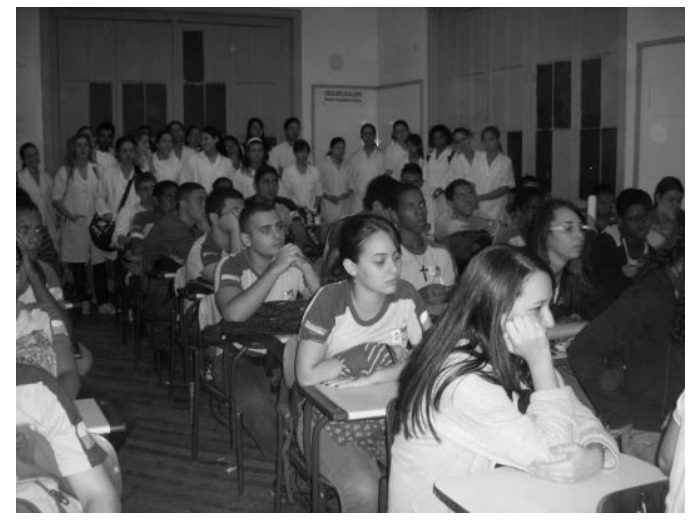

Image 3 - From another angle, students of the $3^{\text {rd }}$ High School grade from the Olinto School.

At the background, Nursing Academics from the UNIRIO

\section{The semiological clue}

After reading the produced images, when we limited the cutting of the signs on the bodies involved in the gatherings, we identified 04 types of images, according to the occupancy space, as show in Table 2.

\begin{tabular}{|c|l|c|}
\hline Territories & \multicolumn{1}{|c|}{ Expressions } & $\begin{array}{c}\text { Total of } \\
\text { students }\end{array}$ \\
\hline $\begin{array}{c}\text { EEAP's Principal } \\
\text { Room }\end{array}$ & $\begin{array}{l}\text { Listener body } \\
\text { and closed in itself }\end{array}$ & 17 \\
\hline Care Factory & $\begin{array}{l}\text { Cheerful and relaxed } \\
\text { body }\end{array}$ & 26 \\
\hline $\begin{array}{c}\text { CEOGB's } \\
\text { Principal Room }\end{array}$ & $\begin{array}{l}\text { Aware body, which is } \\
\text { mindful of the } \\
\text { another which speaks } \\
\text { / cares }\end{array}$ & 90 \\
\hline $\begin{array}{c}\text { Walking across } \\
\text { the CEOGB }\end{array}$ & $\begin{array}{l}\text { Restrained and } \\
\text { expectant body }\end{array}$ & 45 \\
\hline
\end{tabular}

Table 2 - Body expressions in a certain territory

Images analysis took into account the space where the subjects were sitting and their bodily expressions, in the light of COHEN $(2012)^{4}$ and FATORELLI and BRUNO (2006). ${ }^{5}$

\section{RESULTS AND DATA DISCUSSION}

\section{Discussion and inferential analysis}

The search for the SEMIOLOGY of MEETING was triggered in reflections during the extension activities and from the current speech on "welcome". If welcome is "well hosting"; is to R. pesq.: cuid. fundam. online 2013. abr./jun. 5(2):3684-91 find a part of hosting? The general idea that we have is that the meeting casually happens or is programmed. In the first case, the process has no control; in the second, it has theme, date, time and place to happen. Nevertheless, we are not aware of the images, such as facial and body expressions or of the body as a whole, which are transmitted in the meeting in a space where we live, we do something or are together with the other. What the study has shown us is that the meetings might depend on several factors, namely: location, enunciator and enunciatee. Moreover, there is a hierarchy of KNOWLEDGE and POWER - and each one is expressed at the meeting time.

In MEETING with the SCHOOL BOARD, it was a scheduled meeting; the matter of the meeting was the interest of the students and teachers from the CEOGB and our Care Factory Program.

Images 1 and 2 placed here (17 students) show 02 teachers seated at the desks and the students in upright position: the LISTENER BODY and closed in itself. At that moment, the reading the body language was focused on the face and body position, specifically on the arms, when they heard information about the EEAP. Thus, listening and speaking are terms and actions of the first meeting stage; the CHEERFUL and relaxed body, shown in Image 3 (26 students), presents the same students who changed their expression when they were placed into another space - CARE FACTORY on the mats. The body shows a parlance in small details and even if we are not able to explain all the body movements and gestures, we can analyze its main components - body language -, in more detail, then we will examine: body alignment and distance, hands and fingers, arms, feet and toes, swelling, head and shoulders, lips, touch itself; accessories (cell phones). ${ }^{4: 93}$ The images show us students with folded arms. Crossing the arms is a gesture of defending itself. If they are tight against the body, they suggest nervousness, help 
or chronic anxiety, but also might indicate an attempt to self-comfort. It is a gesture that might suggest an embrace, as no one does this, one hugs its own body. If the arms embrace the body without so much strength, it might be an attitude of distrust. Other expressions are presented on the face. Regarding the AWARE BODY and mindful of the other (90 students), this attention was captured in the eyes of students, but it was not possible to clearly realize whether it was a "powerful gaze" or a "lovely gaze", however, seemed to be a "thoughtful gaze", and we could infer that such a fact was arising from the change of territory. ${ }^{4: 99}$ The High School students were now in their space, whereas university teachers and students were, now, those with folded arms, as it appears on the Mosaic 1. Thus, another sign is placed as part of the Semiology of Meeting: FULL BODY closed in the arms and GAZING and LISTENING, as a law to be fulfilled, and at this time there are many expressions on the face and on the gaze; which is gaze of someone who speaks or listens during a meeting, lecture or conference, being that everything is embedded in a non-verbal language. There are three basic rules to keep the flow of a conversation: gazing more at the face of the other when listening; turning away the gaze more when speaking; making brief eye contact to indicate that, in a few seconds, the other should speak. ${ }^{4: 126}$

As to the IMAGES, they are translated as communication objects and are situated like in the boundary between the analogue and digital culture, and what matters, in this unstable and precarious scenario of passages (meetings among students), is to realize those unique elements that are in transit, likely to circumscribe in unprecedented experience modalities. The pictures and/or images of students and teachers analyzed here are prior to the pretensions of the experiences of the Simplified Health Diagnosis, which were understood as a preparation for the meetings that would be performed. It is assumed that "the images and photography itself is endowed with a certain expansive power, as if through them we could have access to a cultural condition". 5:19

Images (4-6) begin the experience, especially the number 6 , which shows, now, all High School students sitting down (in different listening positions) and academic students standing, at the background of the room. All of them are hearers of the teachers' guidelines. There is no doubt that the presentation of the images of this experience of meeting, even conventional, emerges from the fixation of moving pictures, which legitimizes "the pure and direct picture". They are showed as "single framework, banned from any common interference in the moments of capture and image processing." Without being photographers, we have never stopped to consider the tripod as the "necessary and conventional relationship that links the photographer, its equipment and the situation to be recorded." Thus, "the logic of this tripod might be summarized in a vector mode: what is being considered is invariably the direct record (of the meeting), obtained in an unbiased way from a preexisting reality understood as the substrate of the reality". 5:22

Finally, not as terminally this study, which continues interface of many other investigation objects, through images (analogue or virtual), they meet the function of testifying on our experience in the ExLIS Project (2010). They depict the first meetings before the intervention at the School.

Our skills in conducting are not about just knowing how to handle the machine, but to extend what we know about how the body as image of the expression captured at the photograph time of a digital camera.

R. pesq.: cuid. fundam. online 2013. abr./jun. 5(2):3684-91 


\section{CONCLUSION}

In a way, first, we can say that we started a discussion about the SEMIOLOGY of MEETING from photographed experiences and inferences about body image contained therein. From this experience of meeting, it was possible to show that it only happens because there are interests between two or more bodies; that, during the meeting, the bodies express subjective and actual interests which are read by means of gestures and signs of the body language, non-verbal communication. The space where the meeting takes place is where positions of power are at stake and that the bodies, depending on who speaks, are shown: contained in their own world, relaxed and awareness. Through the images, we can observe three times in this study.

What we believe is that this study has its originality in building the Semiology of Meeting as a technical procedure that makes sense, when currently it comes to welcoming, in a "thoughtless" speech on what the term "welcome" means, where the body is the object of this welcoming and/or finding.

If the action of finding involves BODIES, EXPRESSIONS, SPACE, TIME, POWER and INTENTIONALITY, we can propose an image as an outcome of this study (which is first).

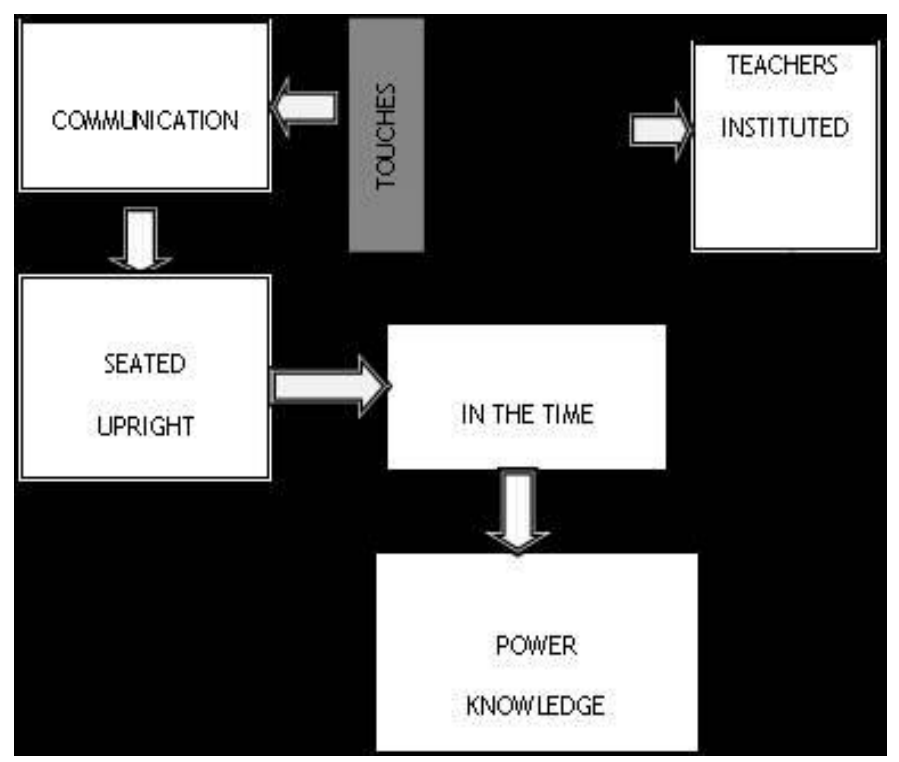

Figure 1 - Semiology of Meeting

R. pesq.: cuid. fundam. online 2013. abr./jun. 5(2):3684-91
For now, we are pursuing constitutive traits of those involved in the meeting, practices and bodily expressions, language and gestures that can expand what we are trying to get in the photographic images, which are attached to the photos by the lived experiences together with secondary and academic students. Hence, it is directed to the elements that are arising from the senses, also singular, culture-related issues and derived from our relationship with each other and with the environment.

Finding ways of expression contained in the body language of the Meeting that is in the environment, streets, public spaces, at the time of caring outside hospitals. The design of a Semiology of Meeting, captured in the photographic image of those involved, might indicate the creation of new fields (for Nursing), in increasingly differentiated ambits of the social life, and that this experience arising from the ExLIS Project (FAPERJ) has brought us "new vectors and addressing expectations of a diverse nature in the current context, where the actions and communications are increasingly held at a distance or in controlled environments." Therefore, it does not end here, since is the first step of the hiking.

\section{REFERÊNCES}

1. Passos E, Kastrup V, Escossia L. (Org.) Pistas do método da Cartografia-pesquisa-intervenção e produção de subjetividade. Porto Alegre: Ed. Sulina; 2009.

2. Figueiredo NMA, Machado WCA. (Org.) Corpo e Saúde: condutas clínicas de cuidar. Rio de Janeiro: Editora Águia Dourada; 2009.

3. Silva MJP. Comunicação tem remédio - a comunicação nas relações interpessoais em saúde. São Paulo: Ed. Loyola; 2002. 
4. Cohen D. A linguagem do corpo - o que você precisa saber. $5^{\mathrm{a} e d .}$ Petrópolis (RJ): Vozes; 2012.

5. Fatorelli A, Bruno F. Limiares da imagem: tecnologia estética na cultura contemporânea. Rio de Janeiro: Manad X; 2006.

\section{Received on: 31/05/2012}

Required for review: No

Approved on: 18/01/2013

Published on: 01/04/2013 